\title{
PENGARUH BUKAAN SUDU PENGARAH TERHADAP TINGKAT KAVITASI DI SISI MASUK PIPA ISAP TURBIN FRANCIS VERTIKAL
}

\author{
Fernando P. Gurning ${ }^{1}$, A.Halim Nasution ${ }^{2}$, Syahril Gultom ${ }^{3}$, Zulkifli Lubis ${ }^{4}$, Farida Ariani ${ }^{5}$ \\ 1.2,3,4,5 Departemen Teknik Mesin, Fakultas Teknik, Universitas Sumatera Utara \\ E-mail : fernando_gurning@ymail.com
}

\begin{abstract}
ABSTRAK
Kavitasi yaitu proses terbentuknya gelembung-gelembung air pada turbin karena tekanan air pada turbin turun menjadi tekanan uap jenuh yang menyebabkan getaran, pengikisan, dan penurunan efisiensi. Fenomena kavitasi tersebut dapat diprediksi dan dihindari dengan menghitung besar tingkat kavitasi turbin yang berasal dari hasil perbandingan nilai angka Thoma aktual dan kritis. Tingkat kavitasi yang diteliti yaitu pada Sisi Masuk Pipa Isap (Draft Tube) di Turbin Francis Vertikal Unit 3 PLTA Siguragura P.T. Inalum (Persero). Tingkat kavitasi sebagai variabel terikat diteliti pengaruhnya dengan bukaan sudu pengarah (Guide Vane Opening/GVO) sebagai variabel bebas pada penelitian ini. Besar GVO yang dipakai dalam penelitian ini ada sembilan variasi yaitu sebesar 19,5 mm; $78 \mathrm{~mm} ; 102 \mathrm{~mm} ; 129,5 \mathrm{~mm} ; 136$ $\mathrm{mm} ; 143 \mathrm{~mm} ; 150 \mathrm{~mm} ; 160,5 \mathrm{~mm}$; dan $195 \mathrm{~mm}$. Berdasarkan penelitian ini diperoleh nilai tingkat kavitasi pada setiap GVO. Tingkat kavitasi diperoleh melalui 2 metode yaitu metode perhitungan dan simulasi. Berdasarkan metode perhitungan diperoleh tingkat kavitasi terbesar pada penelitian ini yaitu sebesar 0,9743 pada GVO sebesar $195 \mathrm{~mm}$, tingkat kavitasi terkecil yaitu sebesar 0,8099 pada GVO sebesar $102 \mathrm{~mm}$; sedangkan pada metode simulasi diperoleh tingkat kavitasi terbesar yaitu sebesar 0,9734 pada GVO $195 \mathrm{~mm}$ dan tingkat kavitasi terkecilnya yaitu sebesar 0,8090 pada GVO $102 \mathrm{~mm}$. Sisi masuk pipa isap tersebut mengalami kavitasi apabila tingkat kavitasinya melebihi nilai 1 atau nilai angka Thoma aktual lebih besar dari nilai angka Thoma kritis. Kavitasi tidak terjadi pada sisi masuk pipa isap apabila tingkat kavitasinya kurang dari nilai 1 atau nilai angka Thoma aktual lebih kecil dari nilai angka Thoma kritis. Jadi, besar GVO yang terbaik untuk menghindari kavitasi di Sisi MasukPipa Isap Turbin Francis Vertikal Unit 3 PLTA Siguragura, yaitu sebesar $102 \mathrm{~mm}$ karena memiliki tingkat kavitasi terkecil; sedangkan besar GVO yang dihindari dan paling rentan terkena kavitasi yaitu sebesar 195 mm karena memiliki tingkat kavitasi terbesar.
\end{abstract}

Kata kunci: Sudu Pengarah, Kavitasi, Pipa Isap, Angka Thoma, Turbin Francis

\section{PENDAHULUAN}

Energi air adalah energi yang diperoleh dari air yang mengalir dan dapat dimanfaatkan secara maksimal dengan menggunakan turbin air. Turbin air adalah mesin penggerak mula yang mengubah energi potensial dan kinetik yang berasal dari aliran air menjadi energi mekanik yang menggerakan generator untuk menghasilkan listrik.

Adapun turbin dibagi menjadi dua berdasarkan aksi air pada sudu turbin yaitu turbin impuls dan turbin reaksi. Turbin impuls contohnya yaitu turbin Pelton dan turbin Cross Flow, sedangkan turbin reaksi contohnya turbin Francis, Turbin Kaplan dan propeller. Pada tugas akhir ini akan dibahas mengenai turbin Francis, khususnya mengenai permasalahan kavitasi yang sering terjadi pada saat beroperasi. Kavitasi yaitu gelembung-gelembung air yang terbentuk akibat penurunan tekanan fluida di turbin yang menyebakan pengikisan, suara, dan getaran, serta menurunkan efisiensi turbin. Fenomena kavitasi tersebut dapat diprediksi dan dihindari dengan menghitung angka Thoma $(\sigma)$ aktual dan kritis agar tidak melewati nilai aktualnya tidak melewati kritisnya.

\section{TINJAUAN PUSTAKA}




\section{Kerugian Head Mayor (Persamaan Hazen-Williams)}

Persamaan ini dikenalkan oleh Gardner Williams dan Allan Hazen pada tahun 1902. Persamaan ini sebagai pengembangan dari persamaan Chezy. Rumus ini pada umumnya dipakai untuk menghitung kerugian head dalam pipa yang relatif sangat panjang seperti jalur pipa penyalur air minum. Persamaan ini lebih mudah digunakan untuk menghitung kerugian pipa secara manual pada sistem yang terdiri dari bermacammacam pipa dibandingkan dengan menggunakan persamaan Darcy-Weisbach. Persamaan ini digunakan hanya untuk aliran turbulen [1].

Bentuk umum persamaan Hazen - Williams [1] ditunjukkan pada persamaan (1) berikut ini.

$$
h_{f}=\frac{10,67 Q^{1,85}}{C^{1,85} D^{4,87}} L
$$

Keterangan:

$h_{f}=$ Kerugian head akibat gesekan (m)

$Q=$ Debit air $\left(\mathrm{m}^{3} / \mathrm{s}\right)$

$D=$ Diameter dalam pipa (m)

$L=$ Panjang pipa (m)

$C=$ Resistance Coefficient

\section{Kerugian Head Minor}

Kerugian head minor terjadi diawal pipa, belokan pipa, perubahan penampang, dan lain - lain (fitting). Kerugian head minor [2] dapat dinyatakan dengan persamaan (2) berikut ini.

$$
h_{m}=\sum n K \frac{v^{2}}{2 g}
$$

Keterangan:

$h_{m}=$ Kerugian head minor $(\mathrm{m})$

$v=$ Kecepatan air dalam pipa $(\mathrm{m} / \mathrm{s})$

$\sum n K=$ Total koefisien kerugian pada fitting

\section{Kavitasi pada Turbin Francis}

Kavitasi berasal dari kata "cavus" yang berarti kosong. Kavitasi adalah suatu peristiwa terjadinya gelembung-gelembung uap di dalam air yang mengalir apabila tekanan di tempat tersebut sama atau di bawah tekanan uap jenuhnya. Air pada kondisi biasa akan mendidih dan menguap pada suhu $100^{\circ} \mathrm{C}$ di tekanan $1 \mathrm{~atm}$, apabila tekanan berkurang sampai cukup rendah, air pada suhu udara lingkungan yaitu sekitar $20^{\circ} \mathrm{C}$ $33^{\circ} \mathrm{C}$ akan mendidih dan menguap. Tempat-tempat bertekanan rendah atau berkecepatan tinggi mudah terjadi kavitasi, terutama pada sisi keluar runner dan bagian masuk pipa isap. Kavitasi akan timbul apabila tekanannya terlalu rendah. Proses terjadinya kavitasi adalah sebagai berikut, air yang mengandung udara atau gelembung-gelembung uap air yang disebabkan oleh adanya kondisi setempat yang tekanannya turun hingga dapat menimbulkan penguapan. Pada tempat yang tekanannya lebih tinggi, maka gelembunggelembung tersebut akan terkondensasi dan pecah dengan tiba-tiba, hal ini akan mengakibatkan tekanan pada sisi masuk pipa isap atau komponen turbin lainnya. Pecahnya gelembung-gelembung ini akan menghasilkan tekanan yang sangat tinggi. Penurunan tekanan aliran didalam turbin air disebabkan perubahan energi tekanan menjadi energi kecepatan (Bernoulli). Makin tinggi kecepatan aliran dan makin 
tinggi temperatur airnya, maka makin tinggi pula bahaya dari pembentukan uap dan kavitasi [3].

\section{Faktor Kavitasi}

Prof. Dietrich Thoma dari Munich, Jerman mengemukakan faktor atau tingkat kavitasi (sigma/angka Thoma) untuk menentukan tekanan dimana turbin dapat bekerja tanpa terkena dampak kavitasi sehingga kavitasi dapat dihindari. Untuk menghindari kavitasi perlu diketahui angka Thoma kritis [4]. Adapun nilai angka Thoma kritis $\left(\sigma_{c}\right)$ yaitu sebagai berikut pada persamaan (3):

dimana:

$$
\sigma_{c}=\frac{p_{a t m}-p_{v}-h_{s}}{h_{\text {efektif }}}
$$

$\sigma_{c} \quad=$ Angka Thoma kritis

$p_{\text {atm }}=$ Head tekanan atmosfer $(\mathrm{m})$

$p_{v} \quad=$ Head tekanan uap jenuh $(\mathrm{m})$

$h_{s} \quad=$ Jarak vertikal antara sumbu pusat runner dan tail water level $(\mathrm{m})$

$h_{\text {eff }}=$ Head efektif $(\mathrm{m})=$ Head maksimum - Kerugian head (head racesampai inlet valve)

Adapun angka Thoma pada saat turbin bekerja disebut angka Thoma Aktual [4].Untuk menghitung nilai aktual dari faktor kavitasi $\left(\sigma_{a}\right)$ yaitu pada persamaan (4) berikut:

$$
\sigma_{a}=\frac{p_{a t m}-p_{\min }-h_{s}}{h_{\text {efektif }}}
$$

dimana:

$\sigma_{a} \quad=$ Angka Thoma aktual

$p_{a t m}=$ Head tekanan atmosfer (m)

$p_{\text {min }}=$ Head tekanan minimum pada komponen turbin yang diteliti (m)

$H_{s} \quad$ = Jarak vertikal antara sumbu pusat runner dan tail water level (m)

$H_{\text {eff }}=$ Head efektif $(\mathrm{m})=$ Head maksimum - Kerugian head dari head race sampai inlet valve)

Agar kavitasi tidak terjadi maka head tekanan minimum $\left(p_{\text {min }}\right)$ harus lebih besar daripada head tekanan uap jenuh cairan $\left(p_{v}\right)$. Selain itu agar tidak terjadi kavitasi maka nilai $\sigma_{a}$ harus lebih kecil daripada nilai $\sigma_{c}$ [4]. Dari keadaan tersebut maka dapat diketahui besarnya tingkat kavitasi, yaitu persamaan (5):

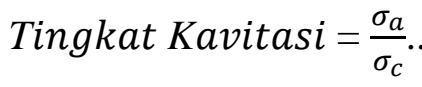

Keterangan: $\quad \sigma_{c}=$ Thoma kritis

$\sigma_{\mathrm{a}}=$ Thoma aktual

Dari rumus diatas jika didapatkan nilai lebih dari 1 maka dapat dipastikan dalam turbin tersebut terjadi kavitasi dan sebaliknya, jika didapatkan nilai kurang dari 1 maka pada turbin tersebut tidak terjadi kavitasi [4].

\section{METODOLOGI PENELITIAN Waktu dan Tempat}


Penelitian dan pengambilan data dilakukan selama 2 hari pada tanggal 14-15 Juli 2014 di PLTA Siguragura P.T. Inalum (Persero) di Paritohan, Kecamatan Pintu Pohan Meranti, Kabupaten Tobasa, Sumatera Utara.

\section{Instalasi Penelitian}

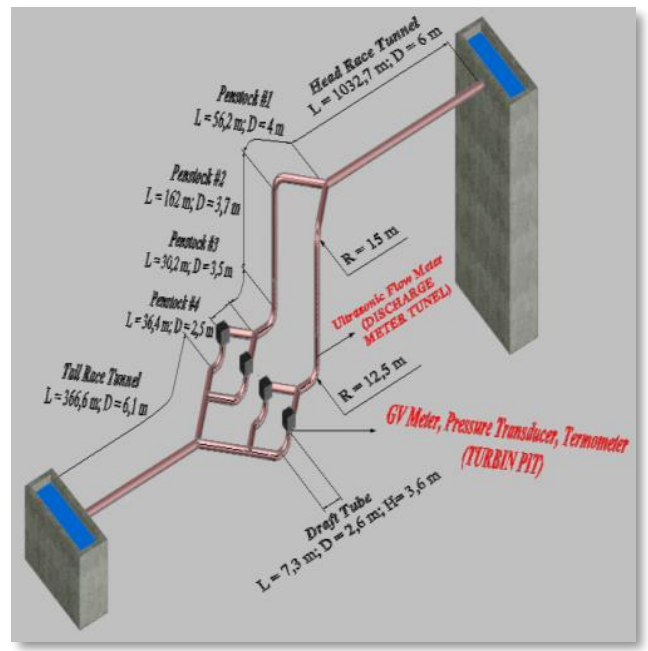

Turbin yang diteliti dalam instalasi penelitian ini adalah Turbin Francis Vertikal Unit-3 PLTA Siguragura. Gambar sederhana tiga dimensi instalasi penelitian pada skripsi ini ditunjukan pada gambar 1.

Gambar 1. Instalasi Penelitian

\section{Metode Pengumpulan Data}

Data yang digunakan dalam penelitian ini terbagi menjadi dua, yaitu:

a. Data primer, merupakan data yang diperoleh dari pengujian PLTA Siguragura P.T. Inalum (Persero), seperti: spesifikasi lengkap turbin Francis vertikal (gambar kerja), head maksimum, debit air masuk turbin, suhu air, dan tekanan minimum di sisi masuk pipa isap turbin, serta survei lapangan yang dilakukan oleh peneliti.

b. Data sekunder, merupakan data yang bersumber dari pustaka-pustaka yang mendukung penelitian.

\section{Metode Pengolahan Data}

Metode pengolahan data yang dipakai dalam penelitian ini terbagi menjadi dua, yaitu:

a. Metode Analisis Perhitungan

Metode analisis perhitungan ini menggunakan rumus-rumus yang bersumber dari pustaka. Adapun rumus yang dipakai seperti: Persamaan Hazen-Williams, rumus head losses minor, persamaan kontinuitas, angka Thoma, dan tingkat kavitasi. Penghitungan dengan menggunakan rumus-rumus tersebut dilakukan di Software Microsoft Office Excel 2007 sehingga data hasil perhitungan dapat ditampilkan dalam tabel dan grafik.

b. Metode Simulasi

Metode simulasi dilakukansebagai pembanding dengan hasil dari metode analisis perhitungan sehingga diperoleh nilai galat. Metode simulasi dalam penelitian ini menggunakan dua software, yaitu Software Pipe Flow Expert V 5.12 (simulasi kerugian head untuk mendapatkan head efektif) dan Software ANSYS Workbench 
14.0 (simulasi tekanan minimum dan uap jenuh di sisi masuk pipa isap/draft tube untuk mendapatkan tingkat kavitasi).

\section{Prosedur Penelitian}

Prosedur penelitian dalam skripsi ini dibagi menjadi tiga yaitu:

\section{a. Prosedur Penelitian dengan Metode Analisis Perhitungan}

1). Diambil data pengujian debit air masuk turbin (Q) di tiap bukaan sudu pengarah (GVO)

2). Ditentukan nilai koefisien kekasaran pipa (C) dari tabel Hazen-Williams

3). Dihitung nilai kerugian head mayor $\left(\mathrm{h}_{\mathrm{f}}\right)$ dengan dimasukkannya nilai $\mathrm{Q}, \mathrm{C}$, L (panjang pipa), D (diameter pipa) pada persamaan Hazen-Williams di setiap bagian pipa turbin.

4). Dihitung kecepatan aliran (v) pipa di setiap bukaan sudu pengarah

5). Ditentukan nilai koefisien kekasaran (K) di setiap komponen kelengkapan pipa berdasarkan tabel koefisien kekasaran komponen kelengkapan pipa

6). Dihitung nilai kerugian head minor $\left(\mathrm{h}_{\mathrm{m}}\right)$ di tiap komponen kelengkapan pipa dengan dimasukkan nilai $\mathrm{K}, \mathrm{v}$, dan $\mathrm{g}$ (percepatan gravitasi) ke persamaan kerugian head minor

7). Dihitung nilai kerugian head total $\left(\mathrm{h}_{\mathrm{L}}\right)$ pada setiap bukaan sudu pengarah

8). Dihitung nilai kerugian head efektif ( $\mathrm{h}_{\text {efektif }}$ ) pada setiap bukaan sudu pengarah

9). Diambil data pengujian tekanan minimum ( $\mathrm{p}_{\min }$ ) dan jarak vertikal antara runner dan tail water level $\left(\mathrm{h}_{\mathrm{s}}\right)$ pada setiap bukaan sudu pengarah

10). Ditentukan nilai tekanan uap jenuh air di turbin $\left(\mathrm{p}_{\mathrm{v}}\right)$ dan tekanan atmosfer $\left(\mathrm{p}_{\mathrm{atm}}\right)$ di permukaan head race dan tail race water level berdasarkan suhu (T) pada saat pengambilan data.

11). Dihitung nilai angka Thoma aktual $\left(\sigma_{a}\right)$ dan kritis $\left(\sigma_{c}\right)$ dengan dimasukkan nilai $\mathrm{p}_{\text {atm }}, \mathrm{p}_{\mathrm{min}}, \mathrm{p}_{\mathrm{v}}, \mathrm{h}_{\mathrm{s}}, \mathrm{h}_{\text {efektif }}$ ke rumus angka Thoma aktual dan kritis

12). Dihitung nilai tingkat kavitasi di setiap bukaan sudu pengarah dengan dibandingkan nilai $\sigma_{\mathrm{a}}$ terhadap $\sigma_{\mathrm{c}}$

13). Diperoleh tingkat kavitasi terbesar dan terkecil dari setiap bukaan sudu pengarah yang diuji.

\section{b. Prosedur Penelitian dengan Metode Simulasi (Software Pipe Flow Expert V 5.12)}

1). Dibuka program Pipe Flow Expert V 5.12

2). Diatur terlebih dahulu satuan (Unit: Metrik)

3). Dibuat reseroir (Head race water level) dengan perintah Add Tanks

4). Ditentukan fluida yang mengalir di turbin dengan dimasukkan spesifikasi sifat air yaitu suhu fluida (T), tekanan fluida (p), massa jenis $(\rho)$, tekanan uap jenuh $\left(\mathrm{p}_{\mathrm{v}}\right)$, surface pressure $\left(\mathrm{p}_{\mathrm{atm}}\right)$, liquid level $\left(\mathrm{h}_{\max }\right)$, bottom elevation (titik acuan)

5). Dibuat sistem jaringan pipa (Head Race Tunnel, Penstock \#1 sampai Penstock \#4) dengan perintah Add Pipes

6). Dimasukkan nilai panjang pipa (Length), diameter dalam (internal diameter), dan kekasaran pipa (roughness) pada tiap pipa

7). Dibuat komponen kelengkapan pipa (Entrance, Gate Valve, Wye Branch, Bending $90^{\circ}$, Gradual Contraction, Spherical Branch, Butterfly Valve) dengan perintah Add Fittings.

8). Dimasukkan nilai elevasi tiap pipa (Elevation of Joint) dan nilai debit aliran air masuk turbin (Add Demand)

9). Diklik calculate untuk diperoleh kerugian head mayor dan kerugian head minor 
10). Dilakukan kembali input data (prosedur nomer 4 dan seterusnya) jika result log tidak berhasil

11). Dilakukan kembali input data (prosedur nomer 8 dan seterusnya) untuk bukaan sudu pengarah yang lainnya dengan diubahnya nilai debit air masuk turbin.

12). Dihitung galatnya antara simulasi dan metode analisis perhitungan

c. Prosedur Penelitian dengan Metode Simulasi (Software ANSYS Workbench 14.0)

1). Dibuat terlebih dahulu geometri pipa isap (Draft Tube) di Solidworks 2010

2). Dilakukan proses import geometri di ANSYS Workbench 14.0 dengan dibukanya file berekstensi STEP File dari Solidwork 2010

3). Dilakukan proses Meshing secara otomatis dengan perintah Generate Mesh

4). Dilakukan proses SETUP dengan diaturnya: Scale (mm); Model (Viscous, Standard k-Epsilon-2 eqn, Standard Wall Functions); Material (Fluid-Water, Solid-Steel); Cell Zone Condition (Type: Fluid); Boundary Condition-Input [Gauge Total Pressure (Pa); Turbulent Intencity (\%), Turbulent Viscousity Ratio]; Reference Values [Density $\left(\mathrm{kg} / \mathrm{m}^{3}\right)$, Pressure (Pa), Temperatur $(\mathrm{K})$, Velocity $(\mathrm{m} / \mathrm{s})$ ]; Solution Method [Momentum dan Turbulent Kinetic Energy (First Order Upwind)]; Monitor [Titik Pengukuran-SurfacePoint-koordinat $(X, Y, Z)]$; Solution Initialization [Standard Initialization, Compute from: Input, Initial Value: Gauge Pressure (Pa), Y Velocity $(\mathrm{m} / \mathrm{s})$ ]; Run Calculation: Number of Iteration.

5). Diklik calculate untuk melakukan proses iterasi tekanan minimum dan uap jenuh fluida di sisi masuk pipa isap

6). Dilakukan kembali prosedur nomer 4 jika iterasi tidak berhasil atau tidak konvergen

7). Diplot kontur tekanan pada surface point di sisi masuk pipa isap dengan menu volume rendering (variabel tekanan) jika iterasi berhasil (konvergen)

8). Dilakukan proses penyimpanan pada program ANSYS

9). Dibuka file Notepad dengan ekstensi outfile sehingga diperoleh hasil iterasi tekanan minimum $\left(\mathrm{p}_{\mathrm{min}}\right)$ dan tekanan uap jenuh $\left(\mathrm{p}_{\mathrm{v}}\right)$ dalam satuan Pascal

10). Dilakukan kembali prosedur nomer 4 dan seterusnya untuk bukaan sudu pengarah lainnya

11). Dihitung galatnya antara simulasi dan metode analisis perhitungan

\section{ANALISA DAN PEMBAHASAN}

\section{Kerugian Head Mayor pada Tiap GVO (Perhitungan dan Simulasi)}

Gambar 2 berikut ini adalah grafik yang menunjukan perbandingan hasil perhitungan antara kerugian head mayor dengan metode analisis perhitungan (persamaan Hazen-Williams) dan simulasi (Software Pipe Flow Expert V 5.12) 


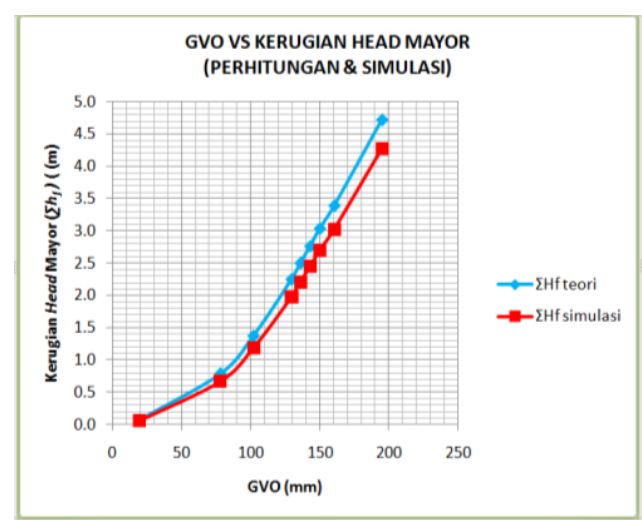

Gambar 2. Grafik Bukaan Sudu Pengarah terhadap Kerugian Head Mayor (Perhitungan dan Simulasi)

Berdasarkan gambar 2 ditunjukkan bahwa galat antara metode analisis perhitungan dan simulasi cukup besar karena kerugian head mayor pada analisis perhitungan menggunakan persamaan Hazen-Williams, sedangkan pada simulasi menggunakan persamaan Darcy-Weisbach. Selain itu, semakin besar bukaan sudu pengarah maka semakin besar kerugian head mayor karena nilai debit aliran air masuk yang semakin besar pula.

\section{Kerugian Head Minor (Perhitungan dan Simulasi)}

Gambar 3 berikut ini adalah grafik hasil perhitungan kerugian head minor antara hasil perhitungan dari analisis perhitungan menggunakan persamaan (2) dan Software Pipe Flow Expert V 5.12.

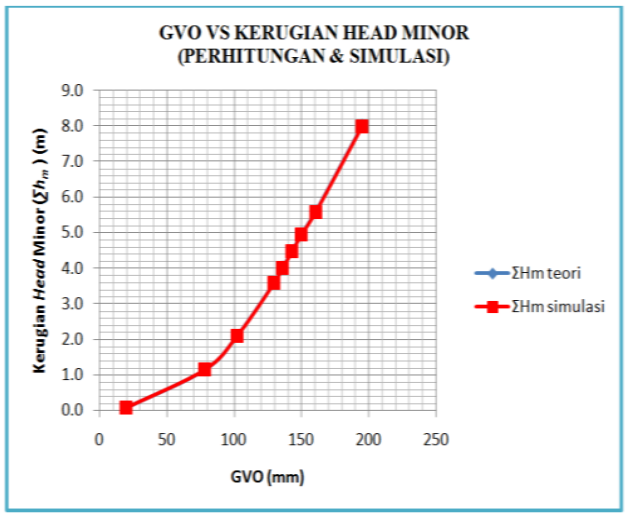

Gambar 3. Grafik Bukaan Sudu Pengarah terhadap Kerugian Head Minor (Perhitungan dan Simulasi)

Berdasarkan gambar 3 ditunjukkan bahwa galat antara metode analisis perhitungan dan simulasi menunjukkan nilai yang sangat kecil sehingga kedua kurva pada grafik berimpit. Hal itu disebabkan karena persamaan yang digunakan antara metode analisis perhitungan dan simulasi sama yaitu dengan menggunakan persamaan (2). Selain itu, semakin besar bukaan sudu pengarah maka semakin besar kerugian head minor karena kecepatan air yang semakin besar pula.

\section{Kerugian Head Total (Perhitungan dan Simulasi)}

Kerugian head total di bawah ini adalah hasil dari penjumlahan kerugian head mayor dan minor dari metode analisis perhitungan dan metode simulasi (Software Pipe Flow Expert V 5.12) yang ditunjukkan pada gambar 4. 


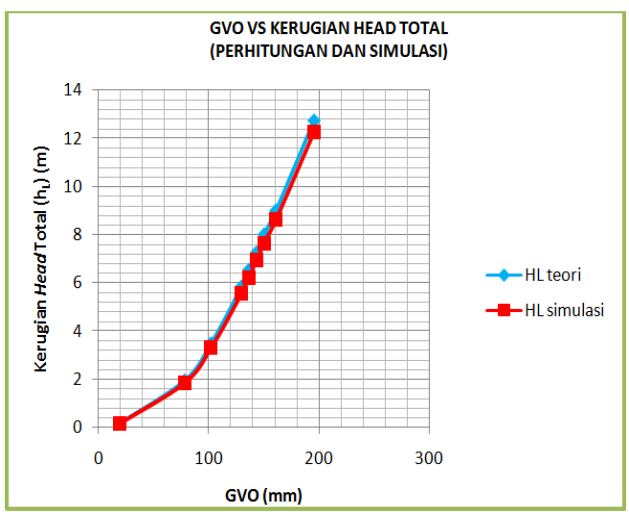

Gambar 4. Grafik Bukaan Sudu Pengarah terhadap Kerugian Head Total (Perhitungan dan Simulasi)

Berdasarkan grafik di atas diperoleh nilai galat dari 3,751\% hingga 8,289\%. Nilai galat terbesar terdapat pada GVO 19,5 mm dan terkecil pada GVO $195 \mathrm{~mm}$. Selain itu, hasil perhitungan kerugian head dengan menggunakan metode analisis perhitungan lebih besar daripada menggunakan simulasi (Software Pipe Flow Expert V 5.12).

\section{Head Efektif pada Tiap GVO (Perhitungan dan Simulasi)}

Head efektif yang dihitung pada penelitian ini merupakan head maksimum pada Turbin yang dikurangi dengan kerugian head total dari gate valve sampai inlet valve yang ditunjukkan pada gambar 5.

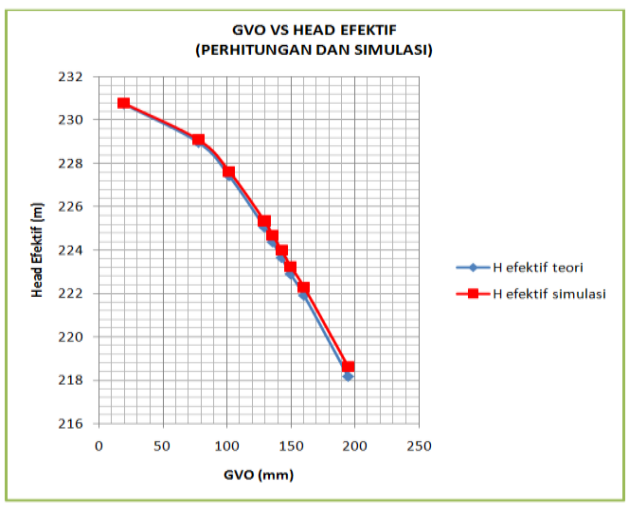

Gambar 5. Grafik Bukaan Sudu Pengarah terhadap Head Efektif (Perhitungan dan Simulasi)

Berdasarkan gambar 5 ditunjukkan bahwa semakin besar bukaan sudu pengarah makan semakin kecil head efektif karena kerugian head yang semakin besar pula.

\section{Hubungan antara GVO dan Tekanan pada Sisi Masuk Pipa Isap (Pengujian)}

Data bukaan sudu pengarah (Guide Vane Opening/GVO) terhadap tekanan minimum $\left(\mathrm{p}_{\min }\right)$ dan tekanan uap jenuh $\left(p_{v}\right)$ di bawah ini merupakan hasil pengujian Turbin Francis Vertikal Unit-3 PLTA Siguragura yang dilakukan oleh P.T. Inalum (Persero) pada tanggal 10 November 2011. Nilai tekanan minimum di diperoleh dari pembacaan alat ukur pressure transducer di turbin pit. Tekanan minimum di atas adalah nilai tekanan yang diperoleh setelah dilakukan pengujian sebanyak 3 kali dan diambil nilai tekanan yang paling kecil $\left(\mathrm{p}_{\mathrm{min}}\right)$.Nilai tekanan uap jenuh pada tiap GVO adalah sebesar 3,491 $\mathrm{kPa}$. Nilai tersebut diperoleh dari interpolasi dari tabel Physical Properties of Water Tekanan uap tersebut terletak pada suhu $26,5^{\circ} \mathrm{C}$ (suhu air yang 
diukur di P.T. Inalum pada tanggal 10 November 2011). Nilai tekanan uap jenuh dalam satuan $\mathrm{kPa}$ dikonversikan menjadi satuan $\mathrm{mH}_{2} \mathrm{O}$ agar memiliki satuan yang sama dengan tekanan minimum pada sisi masuk pipa isap dimana $1 \mathrm{kPa}$ sebanding dengan $0,101972 \mathrm{mH}_{2} \mathrm{O}$. Jadi tekanan uap jenuh di sisi masuk pipa isapsebesar 0,356 $\mathrm{mH}_{2} \mathrm{O}$.

Gambar 6 berikut ini adalah grafik yang menunjukkan menunjukkan hubungan tekanan minimum dan tekanan uap jenuh pada tiap GVO di sisi masuk pipa isap.

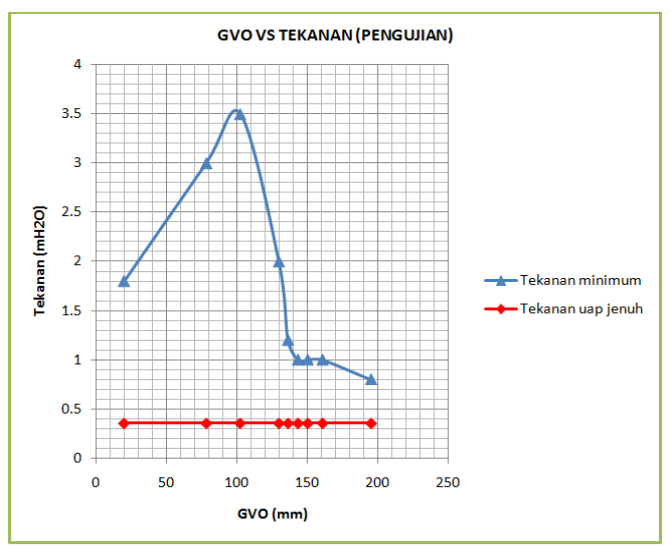

Gambar 6. Grafik Bukaan Sudu Pengarah terhadap Tekanan (Pengujian)

Berdasarkan grafik pada gambar 6 ditunjukkan bahwa pada awal GVO mengalami kenaikkan tekanan dan di pertengahan dan akhir GVO mengalami penurunan tekanan. Tekanan minimum tertinggi yaitu sebesar $3,5 \mathrm{mH}_{2} \mathrm{O}$ pada $\mathrm{GVO} 102$ mm, sedangkan tekanan minimum terendah yaitu sebesar $0,8 \mathrm{mH}_{2} \mathrm{O}$ pada $\mathrm{GVO} 195$ $\mathrm{mm}$. Tekanan uap jenuh memiliki nilai yang tetap karena nilai tersebut akan dijadikan sebagai komponen perhitungan pada nilai angka Thoma kritis yang nilainya juga tetap. Tekanan uap jenuh ini terjadi pada temperatur air konstan yang mengalir di pipa isap yaitu pada suhu $26,5^{\circ} \mathrm{C}$. Nilai tekanan tersebut naik karena head tekanan berubah menjadi head kecepatan, begitu juga sebaliknya [3].

\section{Hubungan antara GVO dan Tekanan pada Sisi Masuk Pipa Isap (Simulasi)}

Gambar 7 berikut ini adalah hasil dari metode penilitian dengan simulasi yang menggunakan Software ANSYS Workbench 14.0 dan dibandingkan dengan nilai tekanan minimum $\left(\mathrm{p}_{\min }\right)$ yang diperoleh dari pengujian dan tekanan uap jenuh $\left(\mathrm{p}_{\text {vapor }} / \mathrm{p}_{\mathrm{v}}\right)$ dari tabel sifat air. Nilai tekanan minimum dan uap jenuh dari metode simulasi diperoleh setelah melakukan iterasi pada software. 


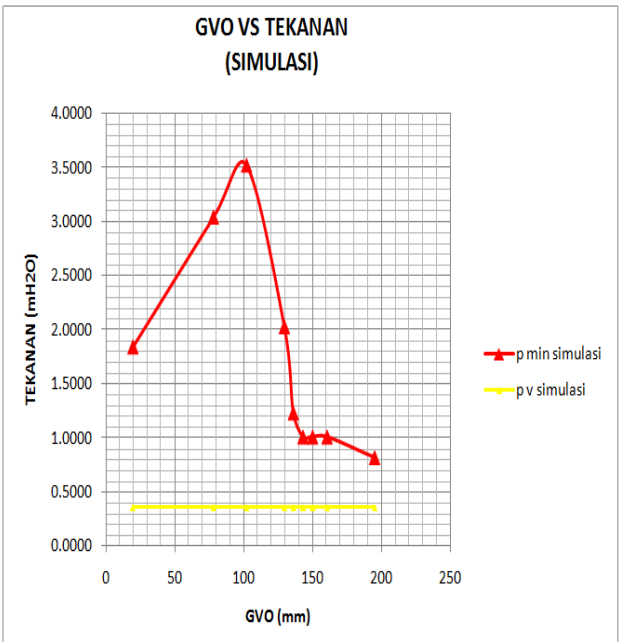

terhadap Tekanan (Simulasi)

Berdasarkan grafik di atas ditunjukkan bahwa Tekanan minimum tertinggi yaitu sebesar 3,5181 $\mathrm{mH}_{2} \mathrm{O}$ pada GVO $102 \mathrm{~mm}$, sedangkan tekanan minimum terendah yaitu sebesar $0,8204 \mathrm{mH}_{2} \mathrm{O}$ pada GVO $195 \mathrm{~mm}$, dan tekanan uap jenuhnya sama pada 0,3603 $\mathrm{mH}_{2} \mathrm{O}$.

\section{Hubungan antara GVO dan Angka Thoma pada Sisi Masuk Pipa Isap (Perhitungan)}

Angka Thoma yang dihitung pada penelitian ini yaitu angka Thoma aktual dan angka Thoma kritis. Angka Thoma kritis $\left(\sigma_{c}\right)$ dihitung berdasarkan persamaan (3) sedangkan angka Thoma aktual $\left(\sigma_{\mathrm{a}}\right)$ dihitung berdasarkan persamaan (4). Gambar 8 berikut ini adalah grafik yang menunjukkan hubungan antara GVO dan angka Thoma aktual dan kritis pada sisi masuk pipa isap dengan menggunakan metode perhitungan.

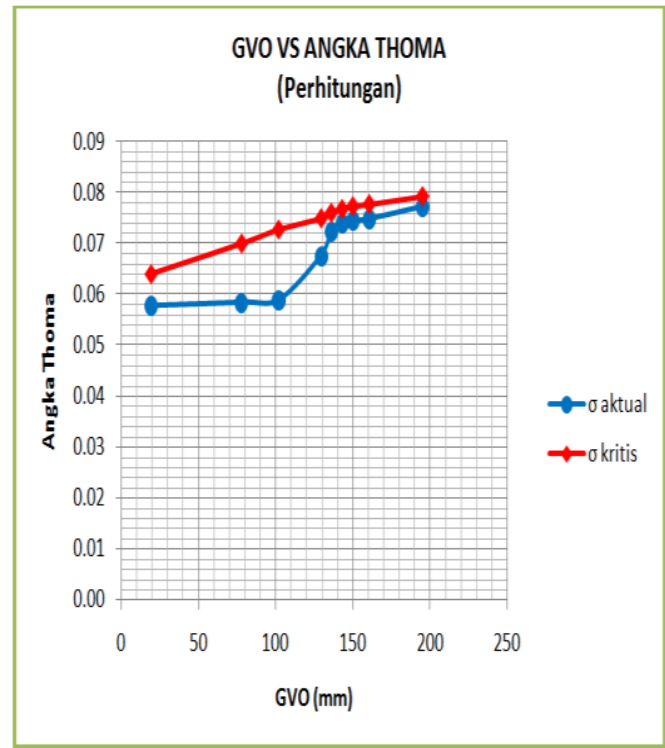

Gambar 8. Grafik Bukaan Sudu Pengarah terhadap Angka Thoma (Perhitungan)

Berdasarkan gambar di atas ditunjukkan bahwa semakin besar GVO maka semakin besar pula angka Thoma aktual dan angka Thoma kritis pada sisi masuk pipa isap. 


\section{Hubungan antara GVO dan Tingkat Kavitasi pada Sisi Masuk Pipa Isap (Perhitungan)}

Tingkat kavitasi dihitung berdasarkan persamaan (5). Gambar 9 berikut ini adalah grafik yang menunjukkan hubungan antara GVO dengan Tingkat Kavitasi pada sisi masuk pipa isap dengan menggunakan metode analisis perhitungan.

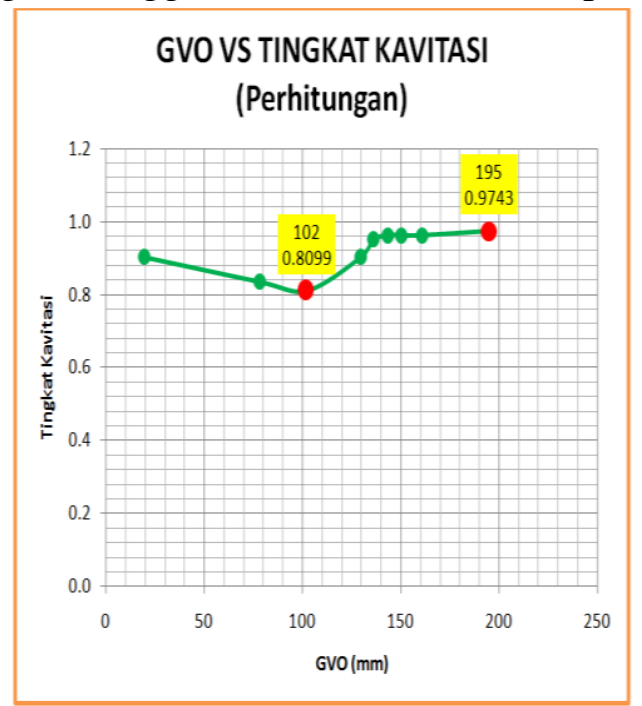

Gambar 9.Grafik Bukaan Sudu Pengarah terhadap Tingkat Kavitasi (Perhitungan)

Berdasarkan grafik di atas ditunjukkan bahwa di awal hingga pertengahan GVO, tingkat kavitasi mengalami penurunan yang tidak terlalu signifikan; sedangkan di pertengahan dan akhir GVO, tingkat kavitasi mengalami peningkatan yang cukup signifikan. Tingkat kavitasi terbesar yaitu sebesar 0,9743 pada GVO $195 \mathrm{~mm}$; sedangkan tingkat kavitasi terkecil yaitu sebesar 0,8099 pada GVO $102 \mathrm{~mm}$. Berdasarkan nilai tingkat kavitasi di atas pada tiap GVO diketahui bahwa pada sisi masuk pipa isap tidak mengalami kavitasi, tetapi nilai yang mendekati 1 (rentan kavitasi) dialami pada tingkat kavitasi terbesar yaitu pada GVO $195 \mathrm{~mm}$. Kenaikan dan penurunan tingkat kavitasi disebabkan oleh perubahan head tekanan menjadi kecepatan dan sebaliknya (Persamaan Bernoulli) [3].

\section{Hubungan antara GVO dan Tingkat Kavitasi pada Sisi Masuk Pipa Isap (Perhitungan dan Simulasi) \\ Tingkat kavitasi pada simulasi dihitung juga dengan menggunakan formula yang sama yaitu berdasarkan persamaan (5) dimana angka Thoma aktual dan kritisnya didapatkan dari nilai tekanan minimum dan tekanan uap jenuh pada metode simulasi. Gambar 10 berikut ini berikut ini menunjukkan hubungan antara GVO dan tingkat kavitasi pada sisi masuk pipa isap.}




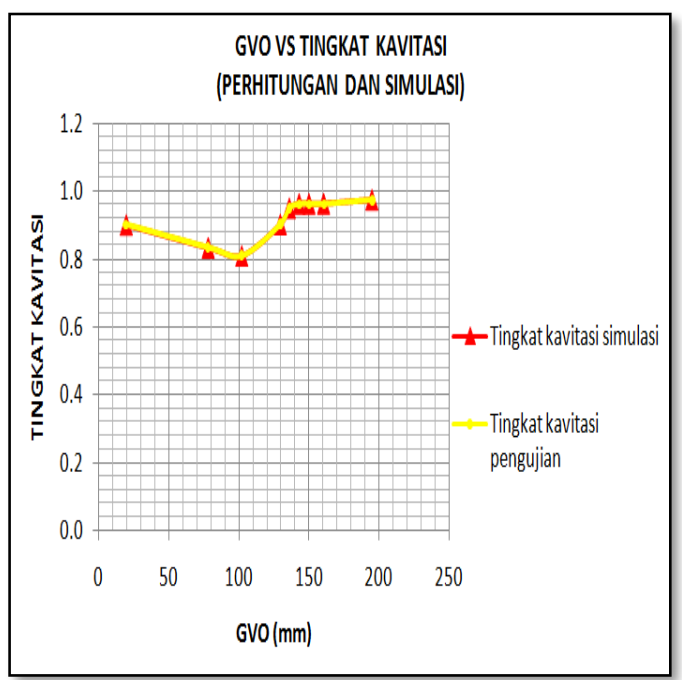

Gambar 10. Grafik Bukaan Sudu Pengarah terhadap Tingkat Kavitasi (Perhitungan dan Simulasi)

Berdasarkan grafik di atas ditunjukkan bahwa tingkat kavitasi pada sisi masuk pipa isap antara metode perhitungan (persamaan 5) dan simulasi (Software ANSYS Workbench 14.0) tidak memiliki perbedaan yang besar karena nilai galat untuk tekanan minimum antara keduanya kecil, yaitu dari 0,0431 \% sampai 0,2910\%. Tingkat kavitasi terbesar pada metode simulasi yaitu sebesar 0,9734 pada GVO $195 \mathrm{~mm}$; sedangkan tingkat kavitasi terkecil pada metode simulasi yaitu sebesar 0,8090 pada GVO $102 \mathrm{~mm}$. Berdasarkan nilai tingkat kavitasi tersebut dapat disimpulkan hal yang sama dengan metode perhitungan yaitu pada sisi masuk pipa isap tidak mengalami kavitasi pada tiap GVO, tetapi nilai yang mendekati 1 (rentan kavitasi) dialami pada tingkat kavitasi terbesar yaitu pada GVO $195 \mathrm{~mm}$.

\section{KESIMPULAN}

a. Tingkat kavitasi terbesar di Sisi Masuk Pipa Isap (Draft Tube) Turbin Francis Vertikal Unit 3 PLTA Siguragura P.T. Inalum (Persero) berdasarkan metode perhitungan yaitu sebesar 0,9743 pada bukaaan sudu pengarah (Guide Vane Opening/GVO) sebesar $195 \mathrm{~mm}$; sedangkan tingkat kavitasi terkecil yaitu sebesar 0,8099 pada GVO sebesar $102 \mathrm{~mm}$. Berdasarkan metode simulasi diperoleh tingkat kavitasi terbesarnya yaitu sebesar 0,9734 pada bukaaan sudu pengarah (Guide Vane Opening/GVO) sebesar $195 \mathrm{~mm}$, sedangkan tingkat kavitasi terkecil yaitu sebesar 0,8090 pada GVO sebesar $102 \mathrm{~mm}$.

b. Kavitasi tidak terjadi pada Sisi Masuk Pipa Isap (Draft Tube) Turbin Francis Vertikal Unit 3 PLTA Siguragura pada GVO $102 \mathrm{~mm}$ karena tingkat kavitasinya (perbandingan angka Thoma aktual dan kritis) di bawah nilai 1 dimana angka Thoma aktual perhitungan dan simulasinya masing-masing adalah 0,0589 dan 0,0588 lebih kecil daripada angka Thoma kritis perhitungan dan simulasinya masing-masing yaitu sebesar 0,0727 dan 0,0726; sedangkan pada GVO 195 mm tidak terjadi kavitasi juga, tetapi rentan mengalaminya karena tingkat kavitasinya mendekati nilai 1 dimana angka Thoma aktual perhitungan dan simulasinya masing-masing adalah 0,0772 dan 0,0769, sedangkan angka Thoma kritis perhitungan dan simulasinya masing-masing sebesar 0,0792 dan 0,0790.

c. Bukaan sudu pengarah (GVO) yang terbaik digunakan untuk menghindari kavitasi di sisi masuk pipa isap turbin yaitu pada $102 \mathrm{~mm}$ karena memiliki tingkat kavitasi terkecil, sedangkan GVO yang dihindari untuk digunakan karena paling rentan 
terkena kavitasi yaitu pada GVO sebesar 195 mm karena memiliki tingkat kavitasi terbesar.

\section{DAFTAR PUSTAKA}

[1] Wikipedia Bahasa Inggris. Hazen-Williams Equation dalam http://en.wikipedia.org/wiki/Hazen\%E2\%80\%93Williams_equation diakses pada tanggal 1 Oktober 2014.

[2] Rayan, Magdy Abou. 2009. A Textbook of Hydraulic Machines. Egypt: Zagagig University.

[3] Dietzel, Fritz. 1988. Turbin, Pompa, dan Kompresor. Jakarta: Erlangga.

[4] Massey, Bernard. 2006. Mechanic of Fluids, Eight Edition. London \& New York: Taylor \& Francis Group. 